\title{
EVALUASI FUNGSI TAMAN KAMPUS EDU PARK UNIVERSITAS MUHAMMADIYAH SURAKARTA SEBAGAI OPEN SPACE KAMPUS
}

\author{
Noor Kholid Ismail, Samsudin \\ Program Studi Teknik Arsitektur, Fakultas Teknik, Universitas Muhammadiyah Surakarta \\ Jl. A. Yani Tromol Pos 1 Pabelan Kartasura Sukoharjo 57102 Telp 0271-717417 \\ Emal : raidi_samsudin@yahoo.co.id
}

\begin{abstract}
ABSTRAK
Latar belakang penelitian ini adalah adanya fenomena disfungsi taman kampus Edu Park UMS sebagai open space kampus yang fungsional. Penelitian ini bertujuan untuk mengetahui hasil evaluasi fungsi taman kampus Edu Park Universitas Muhammadiyah Surakarta. Penelitian ini menggunakan metode pengamatan aktivitas pengguna taman dan metode jajak pendapat dengan melalui penyebaran kuesioner untuk 40 responden. Data yang diperoleh dalam penelitian ini disajikan dalam bentuk tabel, pemetaan, dokumentasi, dan diskripsi. Berdasarkan data pengamatan dan kuesioner terhadap aktivitas pengunjung yang ada, fungsi taman Edu Park sebagai open space sudah dimanfaatkan secara maksimal. Hasil perhitungan kuesioner terhadap 40 responden adalah layak dengan prosentase 35\% aktivitas olahraga, 12,5\% aktivitas jalan-jalan dan bermain, 32,5\% kegiatan foto-foto, 2,5\% kegiatan piknik dan 5\% aktivitas bersepeda. Berdasarkan data kuesioner terhadap elemen pendukung aktivitas yang terdapat pada open space tersebut, menunjukan bahwa taman Edu Park Universitas Muhammadiyah Surakarta sudah digunakan secara maksimal, dibuktikan dengan hasil perhitungan kuesioner terhadap 40 responden bahwa prosentasi yang diperoleh adalah $40 \%$ untuk kategori sangat layak, 55\% untuk kategori layak dan 5\% untuk kategori tidak layak.
\end{abstract}

Kata Kunci: taman kampus, ruang terbuka, edu park

\section{PENDAHULUAN}

Manusia tidak dapat dipisahkan oleh ruang, baik secara psikologis, emosional maupun dimensional. Manusia berada dalam ruang, bergerak, menghayati berfikir, dan membuat ruang untuk menciptakan dunianya. Ruang terbuka (open space) memiliki fungsi sebagai tempat bermain, bersantai, komunikasi, berkumpul, berolahraga, sarana penghubung antara satu tempat dengan tempat lainnya dan pembatas jarak antara massa bangunan. Ruang terbuka juga memiliki fungsi ekologis sebagai penyerap air hujan, memelihara ekosistem, pengendalian banjir dan menghidupkan nilai arsitektur suatu wilayah.

Universitas Muhammadiyah Surakarta merupakan salah satu Universitas yang memiliki open space kampus sebagai wadah kegiatan publik khususnya bagi mahasiswa Universitas Muhammadiyah Surakarta. Namun bila dievaluasi kembali tentang ruang terbuka di Taman Kampus Edu Park Universitas Muhammadiyah Surakarta, fungsi ekologis sebuah open space sebagai penyegaran udara maupun fungsi Taman Edu Park sebagai tempat bermain, berolahraga, bersantai, tempat komunikasi sosial, tempat berpiknik maupun tempat menunggu belum berfungsi secara maksimal bahkan masih ada kondisi taman yang tidak terawat, tidak kondusif, digunakan sebagai tempat berpacaran, dan kurangnya elemen-elemen open space pada beberapa bagian di lokasi taman Edu Park.

Dengan adanya fenomena tersebut maka yang menjadi dasar penelitian ini adalah evaluasi fungsi terhadap Taman Kampus Edu Park Universitas Muhammadiyah Surakarta sebagai open space kampus, berdasarkan fungsi asli sebuah open space. 


\section{TUJUAN PENELITIAN}

a. Mengevaluasi fungsi Taman Kampus Edu Park UMS sebagai open spcae kampus untuk wadah aktifitas publik dan sarana edukasi.

b. Memberikan rekomendasi atau keluaran terhadap perawatan open space untuk menghasilkan sebuah open space yang lebih fungsional, bersih, rapi dan terawat.

\section{MANFAAT PENELITIAN}

a Memahami tentang sebuah open space kampus yang fungsional.

b Dapat digunakan sebagai referensi terhadap perencanaan dan perancangan sebuah open space kampus yang akan dibangun agar dapat berfungsi secara maksimal.

\section{TINJAUAN PUSTAKA}

\section{Ruang Terbuka (Open Space)}

Ruang terbuka merupakan ruang yang direncanakan karena kebutuhan akan tempattempat pertemuan dan aktivitas bersama di udara terbuka (Budihardjo, 1998). Lebih lanjut Budihardjo menyatakan ruang terbuka atau ruang umum pada dasarnya merupakan suatu wadah yang dapat menampung aktivitas tertentu dari masyarakat, baik secara individu maupun kelompok.

\section{Fungsi Ruang Terbuka (open space)}

Menurut Perloff (1969) menyebutkan bahwa open space pada pembentukannya mempunyai fungsi :

1. Menyediakan cahaya dan sirkulasi udara ke dalam bangunan terutama pada bangunan tinggi di pusat kota.

2. Menghadirkan kesan perspektif dan vista pada pemandangan kota (urban scene), terutama pada kawasan padat di pusat kota.

3. Menyediakan area rekreasi dengan bentuk aktivitas yang spesifik.

4. Melindungi fungsi ekologis kawasan

5. Memberikan bentuk "solid-void" kawasan kota.

6. Sebagai area cadangan bagi penggunaan dimasa datang (cadangan area pengembangan).

Menurut Spreiregen (1965) menyebutkan bahwa open space mempunyai 2 fungsi, antara lain :

1. Fungsi Umum Open space
Fungsi umum open space adalah sebagai tempat bermain, berolahraga, bersantai, sarana penghubung antara suatu tempat dengan tempat yang lainnya, pembatas atau jarak antara massa bangunan.

2. Fungsi Ekologis Open space

Fungsi ekologis open space adalah sebagai penyegaran udara, menyerap air hujan, pengendalian banjir, mengurangi polusi suara, memelihara ekosistem dan sebagai pelembut arsitektur ruangan.

\section{Elemen-elemen Pendukung Open space}

Elemen-elemen yang mendukung terbentuknya open space yang fungsional, antara lain:

\section{Soft material}

Merupakan elemen penunjang dan terus berkembang. Golongan yang termasuk soft material adalah:
a. Tanaman penghias
b. Tanaman perdu
c. Tanaman pelindung
d. Ground cover (rumput, lumut)
e. Tanaman merambat

Soft material juga memiliki fungsi sebagai berikut:
a. Menyerap $\mathrm{CO} 2$ dan menghasilkan $\mathrm{O} 2$
b. Memperbaiki iklim setempat
c. Menyerap air hujan
d. Mengurangi polusi suara
e. Mencegah pengikisan tanah

\section{Hard Material}

Hard material merupakan elemen pendukung berupa benda mati dan keras. Berikut adalah hal-hal yang perlu dipahami dalam hard material:
a. Fungsi
b. Karakteristik bentuk bahan
c. Spesifikasi
d. Nilai ekonomis
e. Pasca pemeliharaan dari bahan

Material keras dapat dibagi menjadi 5 kelompok besar, diantaranya:
a. Material keras alami
b. Material kelas alami dari potensi geologi
c. Material kelas buatan bahan metal
d. Material kelas buatan bahan sintesis
e. Material kelas buatan kombinasi

Noor Kholid Ismail, Samsudin - Evaluasi Fungsi Taman Kampus Edu Park Universitas Muhammadiyah Surakarta Sebagai Open Space Kampus 


\section{Signage (rambu-rambu)}

Untuk menciptakan kriteria signage yang fungsional adalah dengan mengatur ukuran, bentuk dan warnanya sehingga dapat dilihat oleh sasaran penerima informasi. Sasaran tersebut bisa berupa pejalan kaki, pengendara motor, atau pengguna fasilitas ruang. Oleh karenanya desain rambu-rambu harus memperhatikan skala ruang dan peletakan rambu-rambu harus diletakkan di tempat yang strategis.

\section{Tipologi Open space Sebagai Taman Umum (Public Park)}

Ruang terbuka publik dalam Permendagri No. 1 tahun 2007 tentang Penataan Ruang Terbuka Hijau Kawasan Perkotaan, adalah ruang-ruang di dalam kota atau wilayah yang lebih luas, baik dalam bentuk area/kawasan maupun dalam bentuk area memanjang/jalur dimana dalam penggunaannya lebih bersifat terbuka yang pada dasarnya tanpa bangunan. Secara historis, menurut Stephen Carr, dkk (1992), macam-macam tipologi ruang terbuka publik:

1. Taman-taman publik (public parks), yang termasuk taman publik adalah:

a. Taman publik/pusat (public/central parks), merupakan bagian dari zone ruang terbuka pada sistem kota yang dibangun dan dikelola oleh publik, pada umumnya berlokasi dekat pusat kota, dan seringkali lebih luas dari taman lingkungan.

b. Taman di pusat kota (downtown parks), merupakan taman hijau dengan rumput dan pepohonan yang berlokasi di daerah pusat kota, dapat berupa taman tradisional dan bernilai sejarah.

c. Taman lingkungan (neighbourhood parks), merupakan ruang terbuka yang dibangun dalam lingkungan permukiman, dibangun dan dikelola oleh publik sebagai bagian dari zone ruang terbuka kota, atau sebagai bagian dari pembangunan perumahan privat baru, biasanya termasuk di dalamnya taman bermain, fasilitas olah raga, dan lain-lain.

d. Taman mini (mini/vest-pocket parks), merupakan taman kota yang berukuran kecil yang dibatasi oleh gedung-gedung, kadang-kadang di dalamnya terdapat air mancur/hiasan air.

2. Lapangan dan plaza (squares and plaza), yang termasuk lapangan dan plaza adalah lapangan pusat (central squares) dan corporate plaza.

3. Taman peringatan (memorial parks), memiliki karakteristik yaitu merupakan tempat umum untuk mengenang seseorang atau peristiwa yang penting bagi suatu daerah, dalam lingkup lokal atau nasional.

4. Pasar (markets), salah satu contoh dari pasar adalah pasar petani (farmer's markets) yang memiliki karakteristik sebagai suatu ruang terbuka atau jalan yang digunakan untuk pasar, dan kadangkadang bersifat temporer.

5. Jalan (streets), yang termasuk jalan adalah trotoar pejalan kaki (pedestrian sidewalks), mal pejalan kaki (pedestrian mall), dilengkapi dengan fasilitas untuk pejalan kaki seperti tanaman dan bangku-bangku, mal tempat transit (transit mall), jalan-jalan yang dibatasi untuk lalu lintas (traffic restricted streets), dan jalan kecil di kota (town trails).

6. Lapangan bermain (playgrounds), yang termasuk lapangan bermain adalah tempat bermain dan halaman sekolah (school yard). Tempat bermain (playgrounds) memiliki karakteristik yaitu area bermain yang berlokasi di lingkungan permukiman.

7. Ruang terbuka untuk masyarakat (community open spaces), yang termasuk di dalamnya adalah lapangan/taman untuk masyarakat (community garden/park) dengan karakteristik yaitu ruang di lingkungan permukiman yang didesain, dibangun, atau dikelola oleh perumahan lokal, di dalamnya termasuk taman, area bermain, dan taman masyarakat.

8. Jalan hijau dan jalan taman (greenways and parkways), memiliki karakteristik yaitu merupakan area alami dan ruang rekreasi yang dihubungkan oleh pejalan kaki dan jalur sepeda.

9. Atrium/pasar tertutup (atrium/indoor market place)

a. Atrium, memiliki karakteristik yaitu ruang privat dalam yang dikembangkan sebagai ruang atrium dalam ruangan, sebuah plasa atau jalur pedestrian dalam ruangan, sebagai bagian dari sistem ruang terbuka, dibangun dan dikelola oleh swasta sebagai bagian dari kantor atau pembangunan komersial baru. 
b. Pasar/pusat perbelanjaan pusat kota (marketplace/downtown shopping center), memiliki karakteristik yaitu area perbelanjaan privat, biasanya merupakan rehabilitas dari bangunan lama, kadangkadang disebut 'Pasar Festival', yang dibangun dan dikelola secara privat atau pembangunan yang bersifat komersial.

10. Found spaces/everyday open spaces, memiliki karakteristik yaitu ruang terbuka yang dapat diakses oleh publik seperti sudut-sudut jalan, jalan menuju gedung, dan lain-lain yang diakui dan digunakan oleh publik, dapat berupa ruang kosong atau ruang yang belum dibangun yang berlokasi di lingkungan tempat tinggal termasuk lahan kosong atau tempat yang direncanakan untuk dibangun, seringkali digunakan oleh penduduk lokal.

Tipologi open space sebagai taman umum masih digolongkan kedalam beberapa tingkatan/tipe berdasarkan karakter yang dimiliki, diantaranya

Tabel.1 Tipologi Open space Sebagai Taman Umum (Publik Park)

\begin{tabular}{|c|c|c|}
\hline \multicolumn{2}{|c|}{ TIPE } & KARAKTERISTIK \\
\hline \multirow{3}{*}{$\begin{array}{l}\sum \\
\sum \\
\sum \\
\sum \\
\sum \\
\sum\end{array}$} & 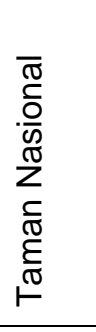 & $\begin{array}{l}\text { - Dikembangkan untuk } \\
\text { Umum. } \\
\text { - Merupakan zona ruang } \\
\text { terbuka yang penting } \\
\text { perannya. } \\
\text { - Terletak dekat pusat kota. } \\
\text { - Memiliki luasan yang lebih } \\
\text { dibanding taman kota. } \\
\end{array}$ \\
\hline & 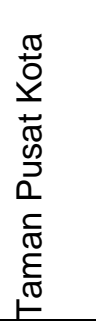 & $\begin{array}{l}\text { - Lapangan rumput hijau } \\
\text { dan pohon pohon yang } \\
\text { terletak dikawasan pusat } \\
\text { kota. } \\
\text { - Bisa berbentuk tradisional, } \\
\text { taman-taman sejarah atau } \\
\text { ruang terbuka } \\
\text { pengembangan baru. }\end{array}$ \\
\hline & 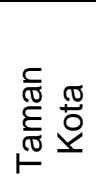 & $\begin{array}{l}\text { - Area hijau kota yang } \\
\text { digunakan untuk kegiatan- } \\
\text { kegiatan santai dan } \\
\text { bermain. }\end{array}$ \\
\hline
\end{tabular}

\begin{tabular}{|c|c|}
\hline 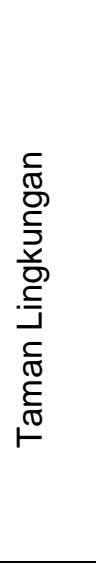 & $\begin{array}{l}\text { - Ruang terbuka yang } \\
\text { dikembangkan di suatu } \\
\text { lingkungan seperti } \\
\text { perumahan, permukiman, } \\
\text { kampus, dll } \\
\text { - Difungsikan untuk } \\
\text { kegiatan umum, dan } \\
\text { merupakan bagian zoning } \\
\text { kota atau bagian } \\
\text { pengembangan suatu area } \\
\text { perumahan / permukiman / } \\
\text { kampus, termasuk fasilitas } \\
\text { bermain, fasilitas olahraga } \\
\text { dan sebagainya. }\end{array}$ \\
\hline 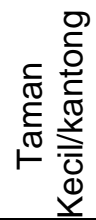 & $\begin{array}{l}\text { - Taman kota kecil yang } \\
\text { dikelilingi oleh bangunan- } \\
\text { bangunan, termasuk air } \\
\text { mancur }\end{array}$ \\
\hline
\end{tabular}

\section{TAMAN (GARDEN) Pengertian Taman}

Menurut Djamal (2005), taman adalah sebidang tanah terbuka dengan luasan tertentu didalamnya ditanam pepohonan, perdu, semak, dan rerumputan yang dapat dikombinasikan dengan kreasi dari bahan lainnya. Umumnya dipergunakan untuk olahraga, bersantai, bermain, berkumpul, dan sebagainya.

\section{Asal Mula Konsep Taman}

Pembuatan taman dilakukan oleh penguasa kuno dalam bentuk penataan lahan pertanian dengan variasi pengairannya merupakan wujud pengakuan akan keindahan alam. Pohon yang rindang, bunga warnawarni, aliran air, batu-batu, dan berbagai elemen lain dianggap sebagai karunia alam yang memiliki nilai estetika tinggi. Bentukbentuk itu kemudian dibawa ke lahan pertaniannya untuk dijadikan taman yang setiap saat dapat dinikmati.

Suatu konsep taman untuk kegiatan bersenang-senang barangkali berasal dari mitologi, mengingat rancangan dan susunannya nampak berasal dari praktek penanaman dan pengairan kuno. Sebagian besar kepercayaan-kepercayaan keagamaan didunia melukiskan taman-taman atau firdaus pada permulaan zaman atau pada akhir kehidupan di muka bumi. 
Dalam Al-Quran, keindahan taman sering digunakan dalam menggambarkan keindahan surga. Dari beberapa ayat dibawah ini, terlihat bahwa unsur air dan tanaman sangat dominan untuk membentuk keindahan taman.

"penghuni-penghuni surga pada hari itu paling baik tempat tinggalnya dan paling indah tempat istirahatnya". QS Al-Furqan (25):24.

"Dan dimasukanlah orang-orang yang beriman dan beramal shaleh ke dalam surga yang mengalir di bawahnya sungai-sungai, mereka kekal didalamnya dengan seizin Tuhan mereka. Ucapan penghormatan mereka dalam surga itu ialah "salaam". QS Ibrahim (14):23.

"Perumpamaan surga yang dijanjikan kepada orang-orang yang takwa ialah (seperti taman), mengalir sungai-sungai didalamnya; buahnya tak henti-henti, sedang naungannya (demikian pula). Itulah tempat kesudahan bagi orang-orang yang bertakwa; sedang tempat kesudahan bagi orang-orang kafir ialah neraka". QA Ar R'ad (13):35.

Dikemukakan oleh Laurie (1986), bahwa taman gantung Babilon merupakan contoh yang unik, dibangun di Lembah Sungai Efrat sekitar 3500 SM. Monumen agung ini dikatakan menempati daerah seluas 4 acre dan meninggi bertingkat-tingkat keatas dalam bentuk serangkaian teras-teras atap yang ditanami pepohonan dan diberi pengairan sampai ketinggian 300 kaki dari mana pemandangan-pemandangan lembah dan padang pasir di sekitarnya dapat dilihat.

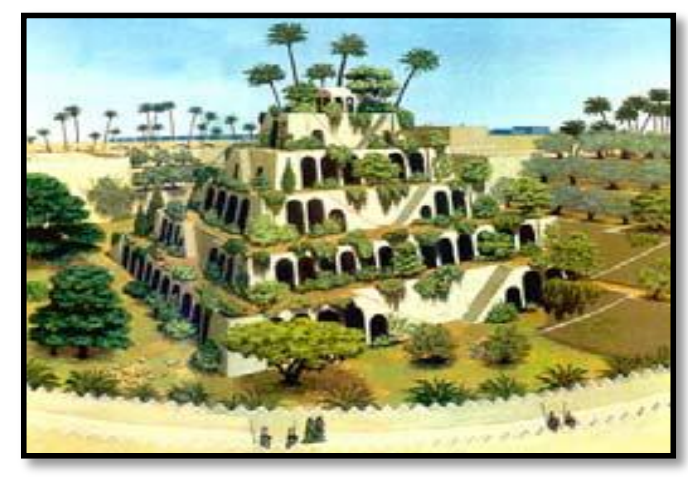

Gambar 1. Taman Babilonia (Sumber: Laurie, 1986)

\section{Taman Dalam Skala Kota}

Taman dalam skala kota adalah sebuah ruang terbuka (open space) dimana didalamnya terdapat aktifitas. Taman sebagai ruang terbuka menjadi pilihan warga kota untuk bersantai atau bersenang-senang secara individu atau kelompok. Pada saat ini taman tidak lagi hanya berfungsi sebagai open space, namun berkembang fungsinya menjadi lebih kompleks, berbagai macam tipe taman memberikan pola-pola aktifitas yang berbeda.

a. Tipe pertama adalah taman yang fungsinya digabung dengan fasilitas olah raga, baik berupa lapangan terbuka dengan street furniture, jogging track, biking, dan olah raga lainnya.Taman menjadi sebuah places for play dan sport park. Taman jenis ini disebut sebagai Taman Aktif.

b. Tipe kedua adalah dimana taman berfungsi sebagai sebuah taman rekreasi dengan fasilitas dan moda-moda penikmatan yang lengkap dan orang-orang membayar untuk menikmatinya. Penikmatan kepada rekreasi secara visual yang melibatkan vista pada tiap-tiap obyeknya. Model taman rekreasi ini dapat dikategorikan sebagai "taman rekreasi pasif".

\section{Elemen Taman}

Menurut Arifin (2006), dalam perancangan taman perlu dilakukan pemilihan dan penataan secara detail elemenelemennya, agar taman dapat fungsional dan estetis. Elemen taman dapat diklasifikasikan menjadi:

a. Berdasarkan jenis dasar elemen meliputi: Elemen alami dan elemen buatan

b. Berdasarkan kesan yang ditimbulkan:

1. Elemen lunak (soft material) seperti tanaman dan satwa.

2. Elemen keras (hard material) seperti ground cover, pagar, schlupture, bangku taman, kolam, lampu taman, patung, pergola.

c. Berdasarkan kemungkinan perubahan:

Taman dalam skala besar (dalam konteks lansekap), memiliki elemen perancangan yang lebih beragam dimana memiliki perbedaan dalam hal kemungkinan dirubah. Elemen tersebut diklasifikasikan menjadi :

1. Elemen mayor (elemen yang sulit diubah), seperti sungai, gunung, pantai, hujan, kabut, suhu, kelembaban udara, radiasi matahari, angin, petir.

2. Elemen minor (elemen yang sulit diubah), seperti sungai kecil, bukit kecil, tanaman, dan elemen buatan manusia. 


\section{METODE PENELITIAN}

Metode penelitian yang digunakan adalah melalui model kualitatif - deskriptif, yaitu mengevaluasi kondisi faktual terhadap semua komponen taman. Kompilasi data dilakukan dengan observasi langsung di lokasi, kemudian disertai wawancara langsung terhadap pihak yang mengetahui kondisi fisik itu dan penyebaran kuesioner terhadap pengguna fasilitas obyek penelitian.

Analisis data dilakukan melalui beberapa proses atau tahapan, karena tahapan awal berasal dari obyek amatan maka penelitian ini merupakan penelitian induktif. Tahapan-tahapan dalam penelitian induktif ini adalah sebagai berikut observasi, stuydi literature, analisis dan pembahasan dan terakhir tahap kesimpulan.

\section{HASIL dan PEMBAHASAN Lokasi Obyek}

Obyek penelitian berada di jalan Adi sucipto, berupa taman edukasi yang ditanami berbagai macam tanaman langka. Kegiatan yang ditampung pada area obyek penelitian ini berupa kegiatan rekreasi, kegiatan olahraga, kegiatan pembelajaran.

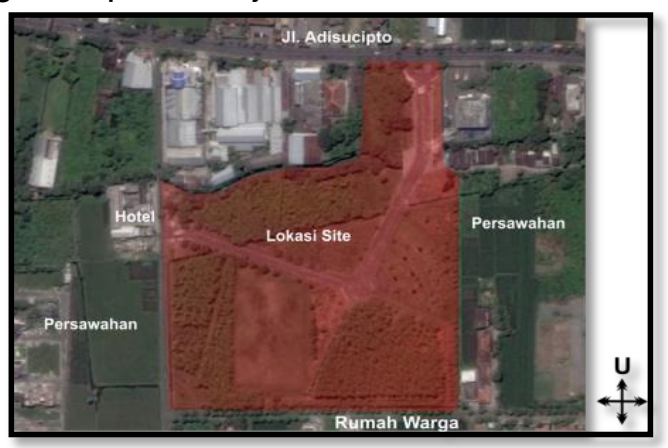

Gambar 2. Lokasi Taman Kampus Edu Park (Sumber: Google Earth, 2015)

\section{Data fisik}

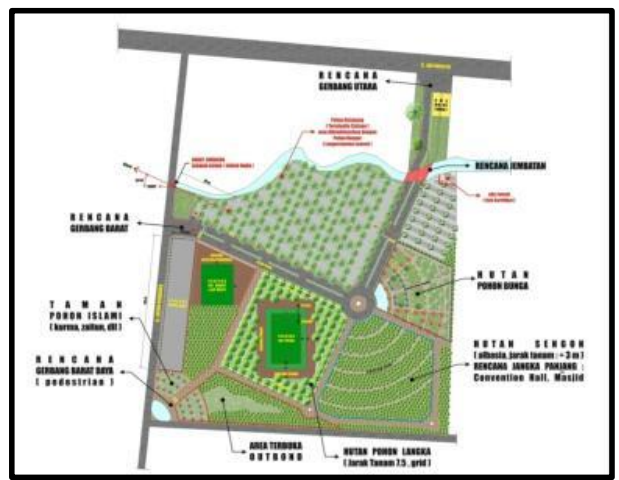

Gambar 3. Situasi Taman kampus Edu Park UMS (Sumber: www.soloaja.com, diakses tanggal 09 januari 2015)
Open space yang didesain dengan konsep edukasi ini memiliki berbagai macam elemen tata ruang luar yang dapat menunjang fungsi dari open space, baik fungsi secara umum maupun secara khusus.

\section{Data Elemen-elemen Penunjang Taman}

\section{Soft Material}

Soft material di taman edupark UMS terdiri dari berbagasi jenis tanaman seperti terlihat pada tabel di bawah.

Tabel 2. Jenis Soft Material di Taman Edupark UMS

\begin{tabular}{|c|c|}
\hline No. & Jenis Tanaman (Soft Material) \\
\hline 01. & Rumput jepang Rumput lia \\
\hline 02 & 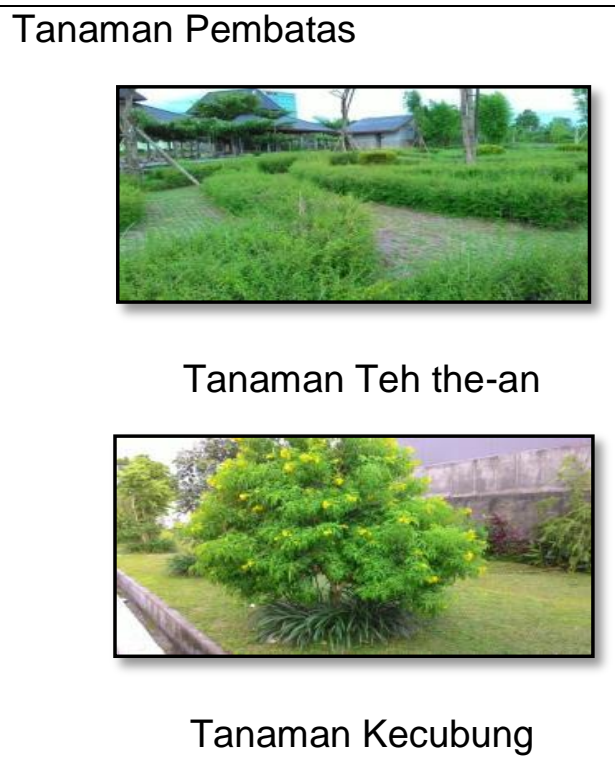 \\
\hline
\end{tabular}

Noor Kholid Ismail, Samsudin - Evaluasi Fungsi Taman Kampus Edu Park Universitas Muhammadiyah Surakarta Sebagai Open Space Kampus 

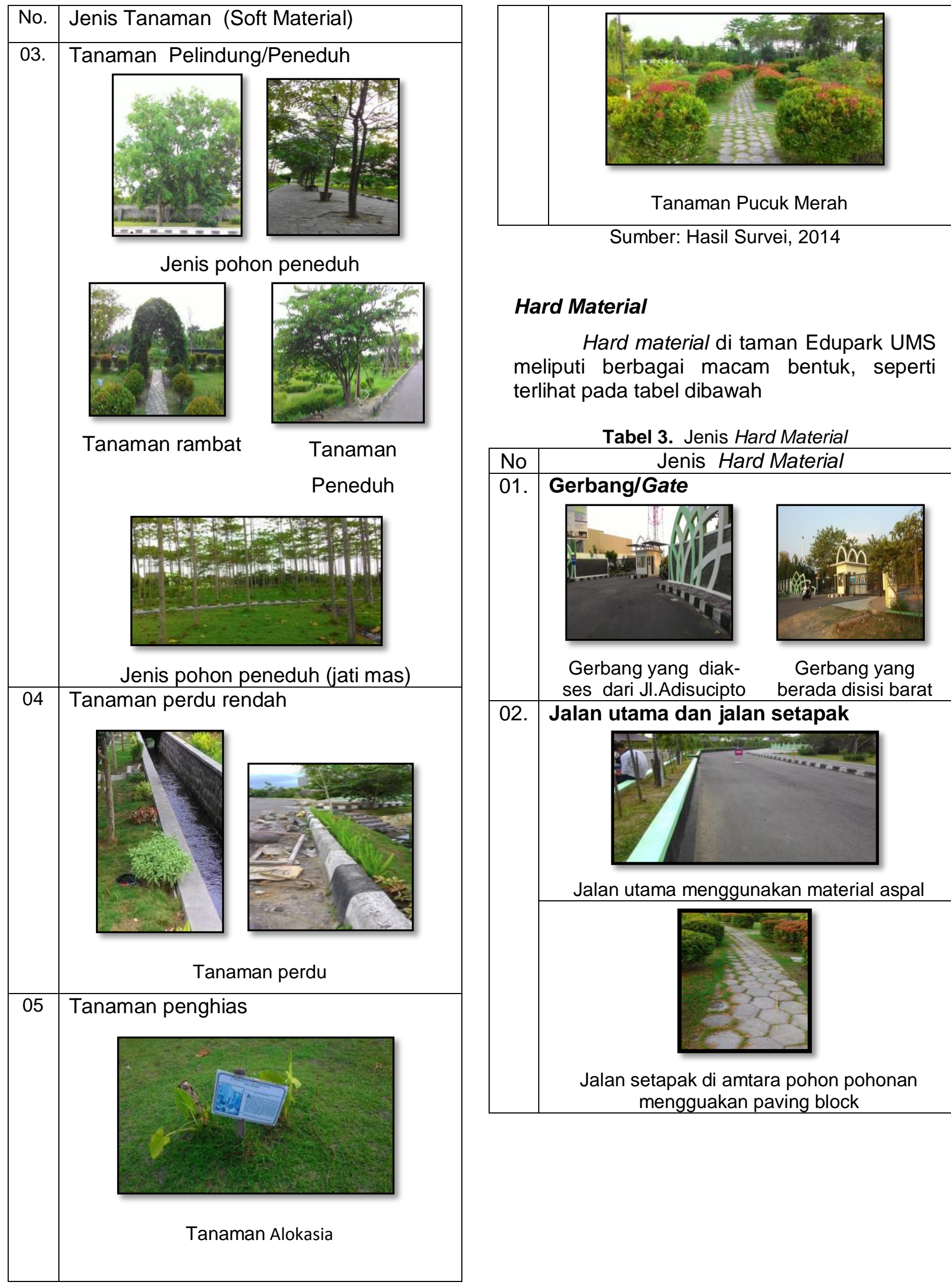

Sumber: Hasil Survei, 2014

\section{Hard Material}

Hard material di taman Edupark UMS meliputi berbagai macam bentuk, seperti terlihat pada tabel dibawah

Tabel 3. Jenis Hard Material

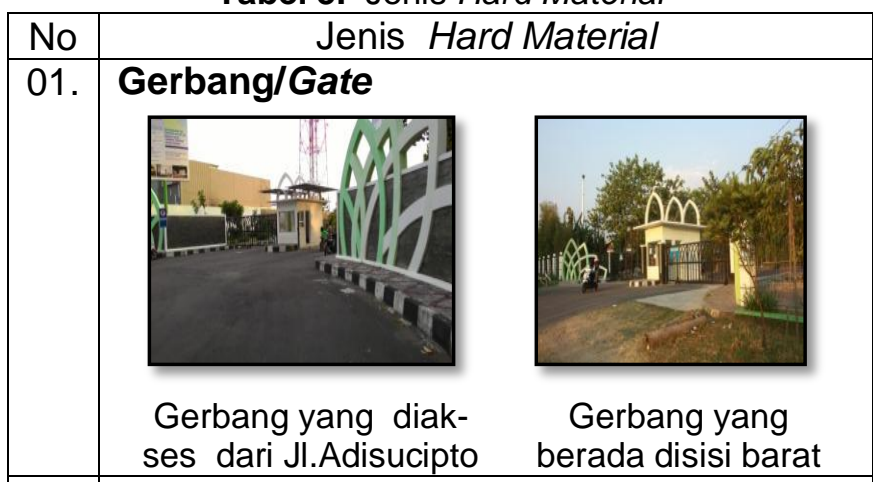

02. Jalan utama dan jalan setapak

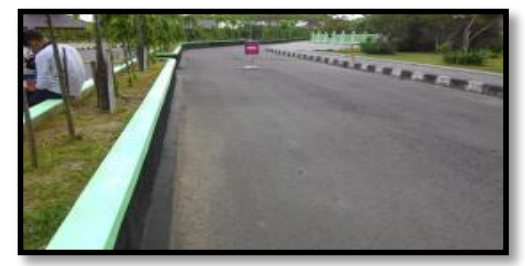

Jalan utama menggunakan material aspal

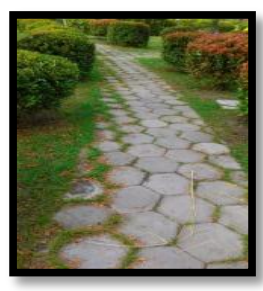

Jalan setapak di amtara pohon pohonan mengguakan paving block 


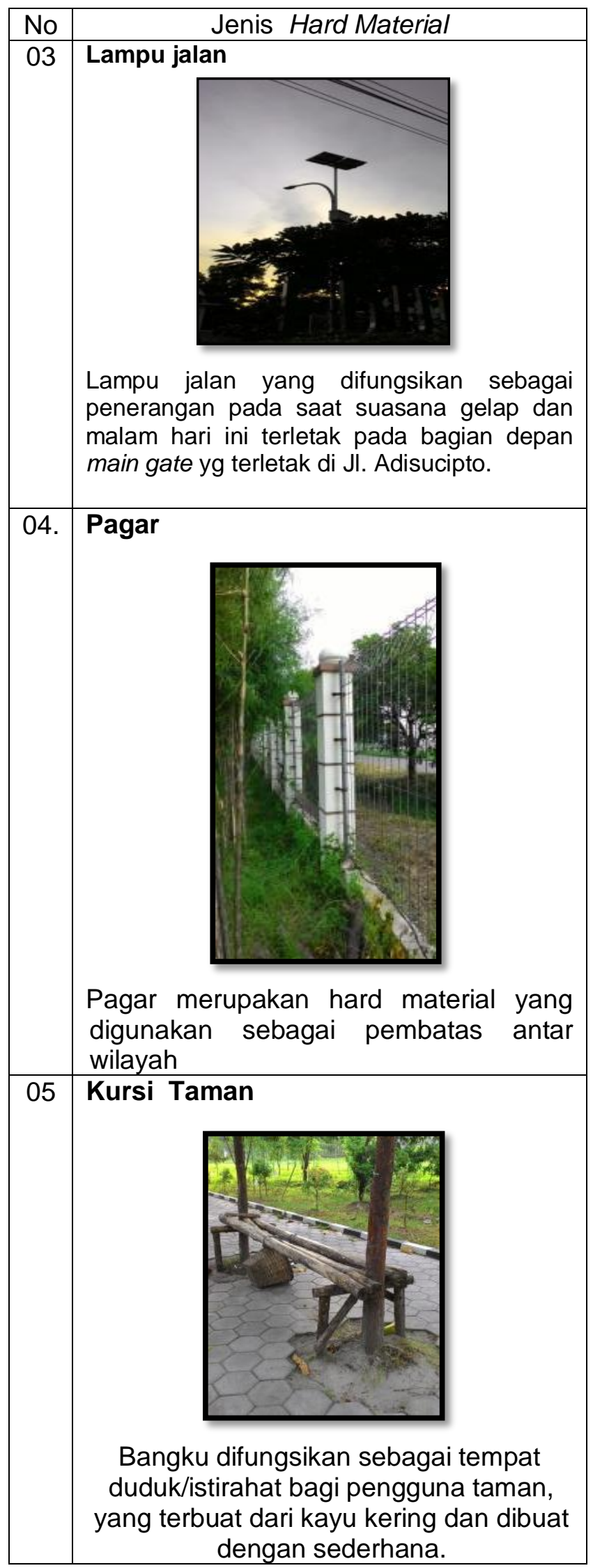

\begin{tabular}{|c|l|}
\hline No & Jenis Hard Material \\
\hline 06 & $\begin{array}{l}\text { Tempat sampah } \\
\text { Tempat sampah sebagai wadah untuk } \\
\text { membuang kotoran, sehingga lingkungan } \\
\text { menjadi lebih bersih dan rapi. }\end{array}$ \\
\hline 07 & $\begin{array}{l}\text { Peneduh } \\
\text { Peneduh yang terdapat pada area } \\
\text { garden ini selain berfungsi sebagai } \\
\text { peneduh juga berfungsi sebagai } \\
\text { penambah nilai estetika pada area } \\
\text { garden }\end{array}$ \\
\hline
\end{tabular}

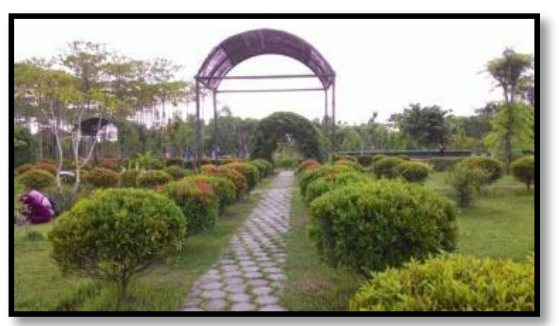

Peneduh yang terletak pada area kebun bunga

\section{Signage}

Pada lingkungan taman Edu Park terdapat beberapa signage, berikut adalah signage yang terdapat pada taman Edu Park
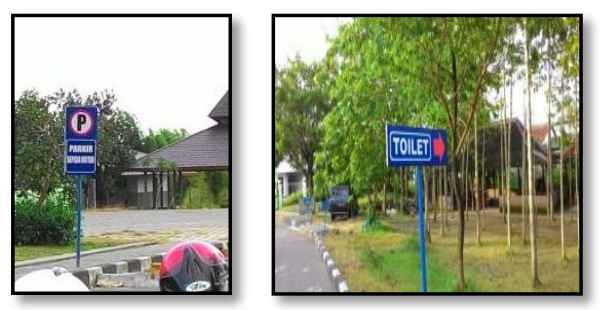

Signage tempat parkir motor dan arah ke toilet
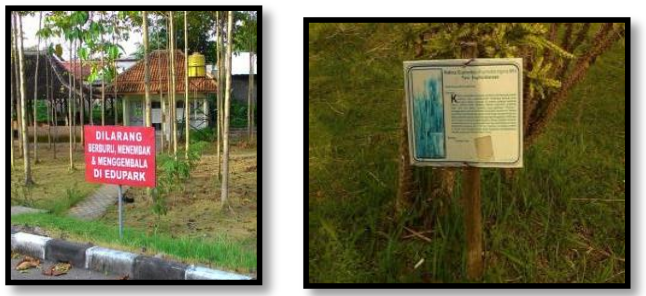

Signage identitas tanaman Sumber: Hasil Survei, 2014 


\section{Data Pengamatan Terhadap Persepsi Pengguna Taman}

Untuk memperoleh berbagai data tentang kegiatan-kegiatan atau aktivitas para pengguna dilakukan selama 1 minggu pada waktu-waktu tertentu sekitar jam 10 pagi, jam 12 siang dan jam 4 sore. Dari hasil observasi atau pengamatan terhadap aktivitas pengguna/pengunjung taman diperoleh data sebagai berikut:

Tabel 4. Data Aktivitas Pada Taman Kampus Edu Park pada jam 10 pagi, jam 12 siang dan jam 4 sore

\begin{tabular}{|c|c|c|c|c|}
\hline \multirow[b]{2}{*}{ No } & \multirow[b]{2}{*}{ Jenis kegiatan } & \multicolumn{2}{|c|}{ Jumlah } & \multirow{2}{*}{$\begin{array}{l}\text { Jumlah } \\
\text { Pelaku } \\
\text { kegiatan }\end{array}$} \\
\hline & & Lk & $\mathrm{Pr}$ & \\
\hline 1 & Olahraga & 55 & 62 & 117 \\
\hline 2 & Bersantai & 58 & 65 & 123 \\
\hline 3 & Foto-foto & 33 & 55 & 88 \\
\hline 4 & Berpacaran & 12 & 12 & 24 \\
\hline 5 & Jalan-jalan & 50 & 47 & 97 \\
\hline 6 & Piknik & 19 & 20 & 39 \\
\hline 7 & Bersepeda & 18 & 20 & 38 \\
\hline 8 & Buang air kecil & 17 & 11 & 28 \\
\hline 9 & Berkumpul & 48 & 45 & 93 \\
\hline \multicolumn{4}{|c|}{$\begin{array}{c}\text { Total jumlah pelaku kegiatan } \\
\text { selama } 1 \text { minggu }\end{array}$} & 647 \\
\hline
\end{tabular}

Sumber: Analasis Peneliti, 2014.

Keterangan: Kondisi cuaca dalam keadaan cerah (tidak hujan).

\section{Data Aktivitas dan Sebaran Lokasi}

Obyek penelitian dibagi menjadi beberapa zona berdasarkan perbedaan fungsi; Untuk mempermudah pengamatan dan pengelompokan data. Pembagian zona atau sebaran lokasi berdasarkan perbedaan fungsi pada obyek amatan tersebut adalah zone $A$, zone $B$, zone $C$ zone $D$ dan zone $E$ (Gambar 4).

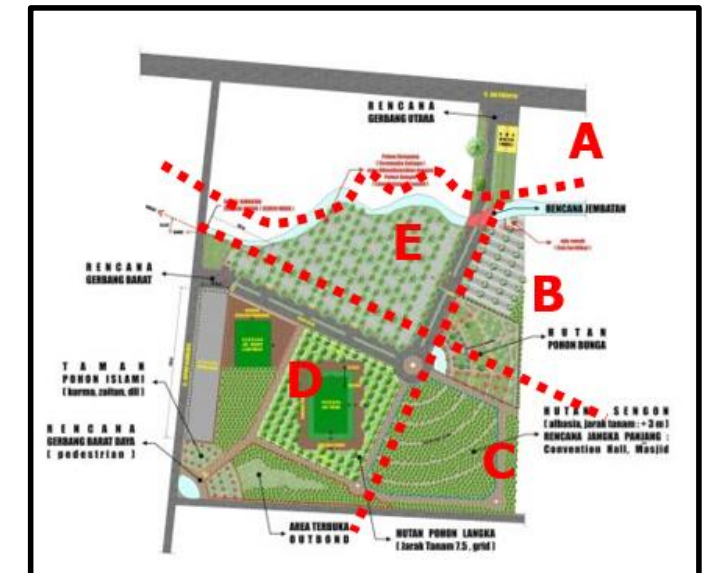

Gambar 4. Pembagian zone data aktivitas dan sebaran lokasi

Simber: Analisis peneliti, 2014

Berdasarlkan pengamatan di lapangan, data yang diperoleh adalah sebagai berikut:

Tabel 5. Data Aktivitas dan Sebaran Lokasi

\begin{tabular}{|c|c|c|c|c|c|c|}
\hline \multirow[t]{2}{*}{ No } & \multirow[t]{2}{*}{ Aktivitas } & \multicolumn{5}{|c|}{$\begin{array}{c}\text { Jumlah Pelaku Aktivitas } \\
\text { Pada Zona }\end{array}$} \\
\hline & & A & B & C & $\mathrm{D}$ & $E$ \\
\hline 1. & Olahraga & 4 & 27 & 37 & 47 & 2 \\
\hline 2. & Bersantai & 6 & 53 & 18 & 43 & 3 \\
\hline 3. & Foto-foto & 7 & 65 & 6 & 8 & 2 \\
\hline 4. & Berpacaran & 0 & 15 & 4 & 0 & 5 \\
\hline 5. & Jalan-jalan & 0 & 48 & 43 & 0 & 6 \\
\hline 6. & Piknik & 0 & 39 & 0 & 0 & 0 \\
\hline 7. & Berkumpul & 0 & 86 & 0 & 7 & 0 \\
\hline 8. & $\begin{array}{c}\text { Buang air } \\
\text { kecil }\end{array}$ & 0 & 0 & 0 & 0 & 28 \\
\hline & Jumlah & 17 & 333 & 108 & 105 & 46 \\
\hline
\end{tabular}

Sumber: Hasil Survey, 2014

\section{Data Kuesioner Terhadap Pengguna Taman}

Pendapat pengguna dijaring menggunakan kuesioner dan menghasilkan data sebagai berikut :

Tabel 6 : Data hasil responden terhadap aktivitas Pengguna

\begin{tabular}{|c|c|c|c|}
\hline No & Aktivitas & Responden & Prosentase \\
\hline 1 & Olahraga & 14 & $35 \%$ \\
\hline
\end{tabular}




\begin{tabular}{|c|l|c|c|}
\hline No & Aktivitas & Responden & Prosentase \\
\hline 2 & Jalan-jalan & 5 & $12,5 \%$ \\
\hline 3 & Foto-foto & 13 & $32,5 \%$ \\
\hline 4 & Bermain & 5 & $12,5 \%$ \\
\hline 5 & Piknik & 1 & $2,5 \%$ \\
\hline 6 & Bersepeda & 2 & $5 \%$ \\
\hline \multicolumn{2}{|c|}{ Jumlah } & 40 & $100 \%$ \\
\hline
\end{tabular}

Sumber: Hasil Survey, 2014.

Tabel 7 : Data hasil responden terhadap lokasi yang sering difungsikan untukmelakukan kegiatan/aktivitas

\begin{tabular}{|c|c|c|c|}
\hline No & Lokasi & Responden & Prosentase \\
\hline 1 & $\begin{array}{l}\text { Taman bunga } \\
\text { tengah }\end{array}$ & 14 & $35 \%$ \\
\hline 2 & Lapangan & 13 & $32,5 \% \%$ \\
\hline 3 & $\begin{array}{ll}\text { Area hutan } \\
\text { pohon }\end{array}$ & 8 & $20 \%$ \\
\hline 4 & $\begin{array}{l}\text { Area samping } \\
\text { rumah } \\
\text { kompos }\end{array}$ & 5 & $12,5 \%$ \\
\hline & Jumlah & 40 & $100 \%$ \\
\hline
\end{tabular}

Sumber: Hasil Survey, 2014

Tabel 8. Data hasil responden terhadap kelayakan Taman

\begin{tabular}{|c|l|c|c|}
\hline No & \multicolumn{1}{|c|}{ Lokasi } & Responden & Prosentase \\
\hline 1 & $\begin{array}{l}\text { Sangat } \\
\text { layak }\end{array}$ & 16 & $40 \%$ \\
\hline 2 & Layak & 20 & $50 \%$ \\
\hline 3 & $\begin{array}{l}\text { Kurang } \\
\text { layak }\end{array}$ & 4 & $10 \%$ \\
\hline 4 & $\begin{array}{l}\text { Tidak } \\
\text { layak } \\
\text { Jumlah }\end{array}$ & 0 & $100 \%$ \\
\hline
\end{tabular}

Sumber: Hasil Survey, 2014

Tabel 9 :Data hasil responden terhadap fasilitas penunjang taman yang masih perlu ditambah/masih kurang

\begin{tabular}{|c|l|c|c|}
\hline No & \multicolumn{1}{|c|}{ Lokasi } & Responden & Prosentase \\
\hline 1. & $\begin{array}{l}\text { Tempat } \\
\text { sampah }\end{array}$ & 7 & $17,5 \%$ \\
\hline 2. & $\begin{array}{l}\text { Kebun } \\
\text { binatang } \\
\text { mini (mini } \\
\text { zoo) }\end{array}$ & 3 & $7,5 \%$ \\
\hline
\end{tabular}

\begin{tabular}{|c|l|c|c|}
\hline No & \multicolumn{1}{|c|}{ Lokasi } & Responden & Prosentase \\
\hline 3. & $\begin{array}{l}\text { Bangku } \\
\text { taman }\end{array}$ & 10 & $25 \%$ \\
\hline 4. & Peneduh & 8 & $20 \%$ \\
\hline 5. & $\begin{array}{l}\text { Identitas } \\
\text { tiap pohon }\end{array}$ & 8 & $20 \%$ \\
\hline 6. & $\begin{array}{l}\text { Tempat } \\
\text { bermain }\end{array}$ & 4 & $10 \%$ \\
\hline & Jumlah & 40 & $100 \%$ \\
\hline
\end{tabular}

Sumber: Hasil Survey, 2014

\section{Evaluasi fungsi open space secara umum}

Layaknya sebuah open space, Taman Edu Park Universitas Muhammadiyah Surakarta merupakan tempat untuk berinteraksi satu orang dengan orang yang lainnya, seperti halnya bermain, olahraga, tempat bersantai, tempat berkomunikasi sosial, tempat peralihan, tempat menunggu, tempat untuk mendapatkan udara segar, sarana penghubung antara suatu tempat dengan tempat yang lainnya, dan pembatas atau jarak diantara massa bangunan.

Berdasakan hasil pengamatan dan kuesioner terhadap aktivitas pengunjung yang ada, fungsi taman Edu Park sebagai open space sudah dimanfaatkan secara maksimal, dibuktikan dengan hasil perhitungan kuesioner terhadap 40 responden bahwa layaknya sebuah open space seluruh aktivitas yang menunjang seperti olahraga, bermain, bersantai, menunggu, berkomunikasi dan jalan-jalan, semuanya sudah terpenuhi dengan prosentae 35\% aktivitas olahraga, $12,5 \%$ aktivitas jalan-jalan dan bermain, $32,5 \%$ kegiatan foto-foto, $2,5 \%$ kegiatan piknik dan $5 \%$ aktivitas bersepeda.

Berdasarkan hasil kuesioner terhadap elemen pendukung aktivitas yang terdapat pada open space tersebut, menunjukan bahwa taman Edu Park Universitas Muhammadiyah Surakarta sudah digunakan secara maksimal, dibuktikan dengan hasil perhitungan kuesioner terhadap 40 responden bahwa prosentasi yang diperoleh adalah $40 \%$ untuk kategori sangat layak, 55\% untuk kategori layak dan 5\% untuk kategori tidak layak.

Meskipun fungsi taman Edu Park Universitas Muhammadiyah Surakarta sudah digunakan secara maksimal dan termasuk

Noor Kholid Ismail, Samsudin - Evaluasi Fungsi Taman Kampus Edu Park Universitas Muhammadiyah Surakarta Sebagai Open Space Kampus 
dalam kategori layak, tetapi ada beberapa fasilitas yang perlu ditambahkan untuk membuat taman Edu Park menjadi lebih maksimal sebagai open space kampus dan sebagai sarana edukasi, diantaranya:

\section{Tempat sampah}

Pada sebagian tempat seperti area kebun bungan dan area antara hutan pohon dengan lapangan sudah terdapat beberapa tempat sampah, namun beberapa tempat seperti area hutan pohon dan sepanjang jalan utama belum ada tempat sampah pada tempat-tempat tersebut sehingga para pengunjung yang sedang berada pada area tersebut kebanyakan membuang sampah sembarangan. Kemudian akan lebih baik jika tempat sampah yang disediakan dibedakan sesuai dengan jenis sampah yang ada, hal ini untuk mendukung tujuan taman Edu Park sebagai sarana edukasi.

\section{Bangku taman}

Bangku taman hanya terdapat pada area antara lapangan dengan hutan pohon sengon. Sehingga kenyamanan pejalan kaki menjadi berkurang. Sebaiknya bangku taman diberikan pada setiap zona.

\section{Kurangnya indentitas tanaman sebagai sarana edukasi}

Taman Edu Park merupakan taman yang bertemakan edukasi, pada pada taman Edu Park UMS hanya sebagian kecil tanaman yang sudah diberi identitas. Selain itu beberapa papan identitas yang tidak terawat membuat papan identitas menjadi rusak dan tulisan yang tertera pada papan menjadi hilang.

\section{Tidak tersedianya lampu taman dalam lingkungan taman}

Tidak tersedianya penerangan yaitu lampu taman pada lingkungan dalam Edu Park sehingga suasana pada malam hari terlihat sangat gelap, hal ini bisa menimbulkan aktivitas negative yang dilakukan orang-orang tidak bertanggung jawab pada suasana gelap.

\section{Kurangnya peneduh pada lokasi taman}

Melalui hasil wawancara terhadap beberapa pengunjung hal yang sering dikeluhkan para pengunjung adalah kurangnya peneduh pada lokasi taman sehingga pada siang hari lokasi taman Edu Park sangat panas, hal ini membuat pengunjung dan pengguna taman menjadi tidak nyaman saat berada atau berkunjung ke taman Edu Park.

\section{Tidak tersedianya tempat pembuangan dan pembakaran sampah organik maupun anorganik}

Tidak adanya tempat untuk membuang dan membakar sampah organik maupun anorganik sehingga pada tempat-tempat tertentu digunkan sebagai tempat pembuangan dan pembakaran sampah. Hal ini sangat mengganggu kebersihan taman dan membuat kondisi taman menjadi tidak rapi, bersih dan nyaman.

\section{Evaluasi Fungsi Open Space Secara Ekologis}

Terdapat berbagai soft material pada taman Edu Park Universitas Muhammadiyah Surakarta menjadikan open space tersebut memiliki berbagai fungsi ekologis sebuah open space kampus yaitu: sebagai penghasil udara segar/O2, mengurangi polutan, sebagai tempat berlangsungnya ekosistem, sebagai penyerap air hujan. Berikut beberapa elemenelemen soft material yang menjadikan taman Edu Park memiliki fungsi ekologis:

\section{Pohon Sengon}

Pohon ini jika ditanam dengan jumlah yang banyak dapat berfungsi untuk mereduksi cahaya, melindungi dari angin dan dapat menciptakan ekosistem baru seperti burung untuk berkembang biak.

\section{Rumput}

Rumput meskipun intensitasnya kecil tanaman jenis ini mampu mengurangi polusi udara.

\section{Bambu cina}

Tanaman ini diletakkan bersebelahan dengan pagar pembatas, selain fungsinya yang sebagai pembatan tanaman ini juga memiliki fungsi ekologis sebagai peredam kebisingan, penyaring udara dan penahan angin.

\section{Evaluasi ditinjau dari Komponen Taman}

Evaluasi fungsi berdasarkan studi literatur dilakukan oleh peneliti dengan cara mengevaluasi kondisi fisik maupun non fisik Taman Kampus Edu Park Universitas Muhammadiyah Surakarta yang ada saat ini dengan ketentuan/kriteria yang seharusnya ada untuk membangun dan menjadikan sebuah open space kampus yang fungsional. 
Tabel 10. Evaluasi ditinjau dari elemen-elemen penunjang Taman

\begin{tabular}{|c|c|c|c|}
\hline No & Kriteria & $\begin{array}{c}\text { Taman } \\
\text { Kampus } \\
\text { Edu } \\
\text { Park }\end{array}$ & Keterangan \\
\hline 1. & $\begin{array}{l}\text { Adanya batasan } \\
\text { fisik oleh unsur } \\
\text { alam (sumber: } \\
\text { spreiregen, 1965) }\end{array}$ & Ada & $\begin{array}{l}\text { Berupa vege- } \\
\text { tasi yaitu } \\
\text { tana-man } \\
\text { bamboo cina } \\
\text { yang } \\
\text { membatasi } \\
\text { antara lingku- } \\
\text { ngan taman } \\
\text { dengan } \\
\text { lingkungan } \\
\text { sekitar. }\end{array}$ \\
\hline \multirow[t]{5}{*}{2.} & $\begin{array}{l}\text { Adanya fasilitas } \\
\text { untuk mewadahi } \\
\text { aktivitas publik } \\
\text { (sumber: } \\
\text { spreiregen, } \\
\text { 1965): }\end{array}$ & & \\
\hline & $\begin{array}{r}\text { Tempat } \\
\text { olahraga }\end{array}$ & Ada & $\begin{array}{l}\text { Berupa lapa- } \\
\text { ngan yang } \\
\text { terletak dekat } \\
\text { pintu masuk } \\
\text { sebelah barat. } \\
\text { Selain itu ter- } \\
\text { dapat juga } \\
\text { jalan setapak } \\
\text { pada area se- } \\
\text { keliling Edu } \\
\text { Park yang } \\
\text { digunakan } \\
\text { sebagai olah- } \\
\text { raga lari. }\end{array}$ \\
\hline & $\begin{array}{l}\text { b. Tempat } \\
\text { bermain }\end{array}$ & Ada & $\begin{array}{l}\text { Terdapat satu } \\
\text { fasilitas } \\
\text { bermain yang } \\
\text { terletak di } \\
\text { pinggir sungai } \\
\text { kecil tetapi } \\
\text { sangat jarang } \\
\text { orang-orang } \\
\text { beraktivitas } \\
\text { pada tempat } \\
\text { tersebut. }\end{array}$ \\
\hline & $\begin{array}{ll}\text { c. } & \text { Tempat } \\
& \text { berkumpul }\end{array}$ & Ada & $\begin{array}{l}\text { Daerah taman } \\
\text { bunga terda- } \\
\text { pat area hijau } \\
\text { yang sering } \\
\text { digunakan } \\
\text { sebagai tem- } \\
\text { pat berkumpul } \\
\text { dan tempat } \\
\text { bersantai. }\end{array}$ \\
\hline & $\begin{array}{ll}\text { d. } & \text { Tempat } \\
& \text { menunggu }\end{array}$ & Ada & $\begin{array}{l}\text { Terdapat } \\
\text { tempat antara } \\
\text { lapangan dan } \\
\text { area hutan } \\
\text { pohon yang } \\
\text { digunakan se- }\end{array}$ \\
\hline
\end{tabular}

\begin{tabular}{|c|c|c|c|}
\hline & & & $\begin{array}{l}\text { bagai tempat } \\
\text { untuk } \\
\text { menung-gu } \\
\text { dan juga } \\
\text { fasilitas yang } \\
\text { disediakan } \\
\text { adalah } \\
\text { bangku yang } \\
\text { dibuat } \\
\text { sederhana } \\
\text { menggunakan } \\
\text { kayu. }\end{array}$ \\
\hline & $\begin{array}{ll}\text { e. } & \text { Area pejalan } \\
\text { kaki }\end{array}$ & Ada & $\begin{array}{l}\text { Berupa } \\
\text { pedes-trian } \\
\text { jalan uta-ma } \\
\text { dan pedes- } \\
\text { trian yang be- } \\
\text { rupa jalan se- } \\
\text { tapak pada } \\
\text { area kebun } \\
\text { bunga, hutan } \\
\text { pohon, dan } \\
\text { sekeliling } \\
\text { area dalam } \\
\text { edu park. }\end{array}$ \\
\hline \multirow[t]{7}{*}{3.} & $\begin{array}{l}\text { Adanya elemen } \\
\text { pendukung: } \\
\text { - Soft material }\end{array}$ & & \\
\hline & $\begin{array}{l}\text { a. Ground } \\
\text { cover }\end{array}$ & Ada & $\begin{array}{l}\text { Berupa } \\
\text { rumput } \\
\text { jepang, } \\
\text { rumput liar } \\
\text { dan rumput } \\
\text { manila } \\
\text { dengan } \\
\text { kondisi yang } \\
\text { terawat. }\end{array}$ \\
\hline & $\begin{array}{ll}\text { b. } & \text { Perdu } \\
& \text { rendah }\end{array}$ & Ada & $\begin{array}{l}\text { Terdiri dari } \\
\text { melanding, } \\
\text { teh-tehan, } \\
\text { pangkas } \\
\text { kuning. }\end{array}$ \\
\hline & $\begin{array}{ll}\text { c. Perdu tinggi } \\
\text { (pembatas) }\end{array}$ & Ada & $\begin{array}{l}\text { Terdiri dari } \\
\text { pohon palm, } \\
\text { bamboo cina, } \\
\text { dan tanaman } \\
\text { kecubung }\end{array}$ \\
\hline & $\begin{array}{ll}\text { d. } & \text { Pohon } \\
& \text { pelindung }\end{array}$ & Ada & $\begin{array}{l}\text { Tediri dari } \\
\text { pohon } \\
\text { angsana, } \\
\text { tanaman } \\
\text { pohon talok, } \\
\text { pohon }\end{array}$ \\
\hline & $\begin{array}{l}\text { e. Tanaman } \\
\text { merambat }\end{array}$ & Ada & $\begin{array}{l}\text { Terletak pada } \\
\text { area kebun } \\
\text { bunga, } \\
\text { tanman } \\
\text { rambat ini } \\
\text { difungsikan } \\
\text { sebagai pene- } \\
\text { duh pada area } \\
\text { kebun bunga. }\end{array}$ \\
\hline & f. Tanaman air & $\begin{array}{c}\text { Tidak } \\
\text { Ada }\end{array}$ & \\
\hline
\end{tabular}




\begin{tabular}{|c|c|c|c|}
\hline & $\begin{array}{l}\text { - Hard material } \\
\text { a. Batu-batuan }\end{array}$ & $\begin{array}{c}\text { Tidak } \\
\text { ada }\end{array}$ & - \\
\hline & b. Schlupture & $\begin{array}{c}\text { Tidak } \\
\text { Ada }\end{array}$ & - \\
\hline & $\begin{array}{ll}\text { C. } & \text { Lampu } \\
& \text { taman }\end{array}$ & $\begin{array}{c}\text { Tidak } \\
\text { Ada }\end{array}$ & \\
\hline & $\begin{array}{l}\text { d. Tempat } \\
\text { duduk }\end{array}$ & Ada & $\begin{array}{l}\text { Terdapat } \\
\text { bangku yang } \\
\text { terletak pada } \\
\text { area antara } \\
\text { la-pangan de- } \\
\text { ngan hutan } \\
\text { pohon, } \\
\text { bangku } \\
\text { tersebut } \\
\text { dibuat } \\
\text { sesederhana } \\
\text { mungkin de- } \\
\text { ngan } \\
\text { menggu- } \\
\text { nakan kayu. } \\
\text { Terdapat }\end{array}$ \\
\hline & $\begin{array}{l}\text { e. Jalan } \\
\text { setapak }\end{array}$ & $\begin{array}{l}\text { Ada } \\
\text { Ada }\end{array}$ & $\begin{array}{lr}\text { pada area } \\
\text { kebun bunga, } \\
\text { area hutan } \\
\text { pohon dan } \\
\text { sekeliling } \\
\text { lapangan. } \\
\text { Terdapat } \\
\end{array}$ \\
\hline & f. Air & & $\begin{array}{l}\text { sungai pada } \\
\text { lingkungan } \\
\text { Edu Park, dan } \\
\text { pada area } \\
\text { pendapa. }\end{array}$ \\
\hline 4. & $\begin{array}{l}\text { Adanya fungsi } \\
\text { ekologis }\end{array}$ & Ada & $\begin{array}{l}\text { Pada area } \\
\text { hutan pohon } \\
\text { sengon, ter- } \\
\text { dapat ekosis- } \\
\text { tem burung } \\
\text { yang menam- } \\
\text { bah suasana } \\
\text { ramai pada } \\
\text { area taman, } \\
\text { adanya resa- } \\
\text { pan air hujan } \\
\text { yang dibuat } \\
\text { dekat dengan } \\
\text { kebun bunga, } \\
\text { dan area } \\
\text { ping-gir dekat } \\
\text { de-ngan } \\
\text { pagar } \\
\text { pembatas } \\
\text { yaitu tanaman } \\
\text { bambu cina } \\
\text { sebagai pere- } \\
\text { dam kebisi- } \\
\text { ngan, penya- } \\
\text { ring udara } \\
\text { dan penahan } \\
\text { angin. }\end{array}$ \\
\hline
\end{tabular}

Sumber: Analisis Peneliti, 2014

\section{Evaluasi ditinjau dari Tipologi Taman}

Hasil evaluasi diperlihatkan pada tabel dibawah ini:

Tabel 11. Hasil Analisis berdasarkan Tipe Taman

\begin{tabular}{|c|c|c|c|}
\hline \multicolumn{2}{|c|}{ TIPE } & KARAKTERISTIK & \multirow{2}{*}{$\begin{array}{c}\begin{array}{c}\text { Taman } \\
\text { Edu } \\
\text { Park }\end{array} \\
\text { Tidak } \\
\text { Sesuai }\end{array}$} \\
\hline \multirow{4}{*}{$\begin{array}{l}\text { TAMAN } \\
\text { UMUM }\end{array}$} & $\begin{array}{l}\text { Taman } \\
\text { Nasional }\end{array}$ & $\begin{array}{ll}\text { - } & \text { Dikembangkan } \\
\text { untuk Umum. } \\
\text { - } & \text { Merupakan } \\
\text { zona ruang } \\
\text { terbuka yang } \\
\text { penting } \\
\text { perannya. } \\
\text { Terletak dekat } \\
\text { pusat kota. } \\
\text { Memiliki luasan } \\
\text { yang lebih } \\
\text { diban-ding } \\
\text { taman kota. }\end{array}$ & \\
\hline & $\begin{array}{c}\text { Taman Pusat } \\
\text { Kota }\end{array}$ & $\begin{array}{ll}\text { - } & \text { Lapangan } \\
\text { rumput hijau } \\
\text { dan pohon } \\
\text { pohon yang } \\
\text { terletak } \\
\text { dikawasan } \\
\text { pusat kota. } \\
\text { Bisa berbentuk } \\
\text { tradisional, } \\
\text { taman-taman } \\
\text { sejarah atau } \\
\text { ruang terbuka } \\
\text { pengembangan } \\
\text { baru. } \\
\end{array}$ & $\begin{array}{l}\text { Tidak } \\
\text { Sesuai }\end{array}$ \\
\hline & Taman Kota & $\begin{array}{l}\text { Area hijau kota } \\
\text { yang } \\
\text { digunakan } \\
\text { untuk kegiatan- } \\
\text { kegiatan santai } \\
\text { dan bermain. }\end{array}$ & $\begin{array}{l}\text { Tidak } \\
\text { Sesuai }\end{array}$ \\
\hline & $\begin{array}{c}\text { Taman } \\
\text { Lingkungan }\end{array}$ & $\begin{array}{l}\text { Ruang terbuka } \\
\text { yang } \\
\text { dikembangkan } \\
\text { di suatu } \\
\text { lingkungan } \\
\text { seperti } \\
\text { perumahan, } \\
\text { permukiman, } \\
\text { kampus, dll } \\
\text { Difungsikan } \\
\text { untuk kegiatan } \\
\text { umum, dan } \\
\text { merupakan } \\
\text { bagian zoning } \\
\text { kota atau } \\
\text { bagian } \\
\text { pengembangan } \\
\text { suatu area } \\
\text { perumahan / } \\
\text { permukiman / } \\
\text { kampus, } \\
\text { termasuk }\end{array}$ & Sesuai \\
\hline
\end{tabular}




\begin{tabular}{|c|c|c|}
\hline & $\begin{array}{l}\text { fasilitas } \\
\text { bermain, } \\
\text { fasilitas } \\
\text { olahraga dan } \\
\text { sebagainya. }\end{array}$ & \\
\hline $\begin{array}{c}\text { Taman } \\
\text { Kecil/kantong }\end{array}$ & $\begin{array}{l}\text { - Taman kota } \\
\text { kecil yang } \\
\text { dikelilingi oleh } \\
\text { bangunan- } \\
\text { bangunan, } \\
\text { termasuk air } \\
\text { mancur }\end{array}$ & $\begin{array}{l}\text { Tidak } \\
\text { Sesuai }\end{array}$ \\
\hline
\end{tabular}

Sumber: Analisis Peneliti, 2014

\section{KESIMPULAN}

Dari hasil analisis terhadap Evaluasi Fungsi Taman Kampus Edu park UMS sebagai Open space Kampus yang Fungsional, dapat disimpulkan bahwa:

1. Berdasarkan hasil analisis dan Evaluasi Taman Kampus Edu park yang ditinjau dari fungsi open space secara umum, fungsi open space secara ekologis, komponen taman, tipologi taman, taman Edu park ini termasuk taman kampus yang fungsional.

2. Adanya aktivitas publik di taman Edu park yang didominasi oleh aktivitas olahraga dan bersantai dengan adanya elemenelemen pendukung open space mampu menjadikannya sebagai open space dengan tipe taman lingkungan.

3. Adanya fasilitas yang harus ditambahkan supaya menjadikan taman Edu park lebih maksimal sebagai open space kampus dan sarana edukasi, diantaranya:
a. Tempat sampah
b. Bangku taman
c. Kurangnya identitas taman sebagai sarana edukasi
d. Kurangnya peneduh pada lokasi taman
e. Tidak tesedianya pembuangan dan pembakaran sampah organik maupun anorganik.

4. Adanya aktivitas publik yang tidak merata yaitu pengunjung lebih sering mengunjungi area pada zona $B$ dan area yang jarang sekali dikunjungi adalah zona E. Hal ini disebabkan oleh elemen-elemen pendukung yang dibutuhkan para pengunjung, diantaranya:

a. Terdapat tanaman bunga sehingga area tersebut menjadi indah.

b. Terdapat ground cover sehingga pengunjung bisa duduk dan istirahat pada area tersebut.

c. Adanya tanaman penedu

\section{SARAN}

Dalam Perancangan sebuah open spacefungsi umum sangat diperhatikan, sebagai tempat bermain, olahraga, tempat bersantai, tempat komunikasi sosial, tempat menunggu, sarana penghubung antara massa bangunan, dan elemen-elemen pendukungnya yang dibutuhkan untuk menunjang aktivitas yang ada dalam open space.

Pada pengelola peneliti ingin memberikan saran antara lain:

1. Untuk sebuah taman sebagai sarana edukasi hendaknya sebuah taman harus memiliki fasilitas yang mampu mewadahi aktivitas edukasi yang ada diantaranya: pembelajaran akan tumbuhan dengan memberi identitas pada setiap vegetasi, terdapat ekosistem satwa yang dipelihara dan dirawat.

2. Untuk lokasi tempat parkir kurang nyaman karena menurut data tempat parkir berada pada jalur utama, sebaiknya perlu dibuatkan wadah untuk tempat parkir supaya lingkungan taman terlihat rapi dan terhindar dari view buruk yang disebabkan oleh tempat parkir yang tidak tertata.

3. Perlu adanya manajemen yang mengurus dan mengatur kondisi pada taman Edu park, supaya taman kampus Edu park lebih terawat dan terjaga kondisi fisik maupun non fisiknya.

\section{DAFTAR PUSTAKA}

Departemen Agama, 2007. Al Quran.

Arifin, Hadi S, 2006, Taman Instan, Penebar Swadaya, Jakarta. 
Asih, Dwi dan Tri, Nugroho, 2005, Laporan Penelitian Evaluasi Fungsi Taman Air Kalianyar Tirtonadi Sebagai Open Space Kota Yang Fungsional, Universitas Muhammadiyah Surakarta, Surakarta.

Carr, Stephen, 1992, Publick Space, Cambridge University Press, Cambridge

Darmawan, Edy, 2005, Analisa Ruang Publik Arsitektur Kota, Univesitas Diponegoro, Semarang.

Djamal, Irwan, 2005, Tantangan Lingkungan \&Lanskap Hutan Kota,Bumi Aksara, Jakarta.

Spreiregen, Pal D, 1965, The Architecture of Town Cities, American Institute of America, New York.

Google Earth tahun 2014.

http://www.soloraja.com, tahun 2014 